\title{
Polioxometalatoak: Elhuyar anaien ametsak bizirik dirau!
}

\author{
(Polyoxometalates: Elhuyar brothers' dream alive \\ and kicking!)
}

\author{
Beñat Artetxe ${ }^{1 *}$, Santiago Reinoso ${ }^{2}$, Juan M. Gutiérrez-Zorrilla ${ }^{1}$ \\ ${ }^{1}$ Kimika Ez-organikoa Saila, Zientzia eta Teknologia Fakultatea. \\ Euskal Herriko Unibertsitatea, UPV/EHU. \\ ${ }^{2}$ Institute for Advanced Materials, InaMat. Nafarroako Unibertsitate Publikoa. \\ *benat.artetxe@ehu.eus
}

DOI: $10.1387 /$ ekaia.17686

Laburpena: Polioxometalatoak (POMak) kimika ez-organikoaren munduan ezagunak diren metalez eta oxigenoz osatutako kluster anionikoak dira. Azaldu ohi duten forma, konposizio eta propietate aniztasunaren ondorioz, POMek aplikazio ugari dituzte teknologiari, ekonomiari edo ingurugiroari lotutako arlo ezberdinetan. Nahiz eta aspaldidanik aplikazio katalitikoetan erabili, gaur egun etorkizunerako garrantzitsuak izango diren esparru oso ezberdinetarako ikertzen ari dira, besteak beste, hondakin-uren tratamenduan, medikuntzan, konputazio kuantikoan, energia-iturri berriztagarrietan edota sentsore kimiko lumineszenteetan. Horrengatik guztiagatik, polioxometalatoen kimika, etorkizun handiko kimika ezorganikoaren alorreko esparru dinamikoenetariko bat dela baiezta genezake.

Hitz gakoak: polioxometalatoak, materialen zientzia, katalisia, nanozientzia, sentsore lumineszenteak, medikuntza.

\begin{abstract}
Polyoxometalates (POMs) are a well known class of anionic metal-oxygen clusters within the area of inorganic chemistry, with a large variety of shapes, compositions and structures. These features make POMs unique compounds with a wide range of applications in current fields of interest related to technology, economy and environment. In spite of their traditional use as catalysts, they are nowadays being explored for very different issues such as wastewater treatment, medicine, quantum computing, renewable energies or luminescent sensors. Therefore, POM chemistry can be considered as one of the most dynamic fields of the inorganic chemistry, as well as one of the fields with the greatest future.
\end{abstract}

Keywords: polyoxometalates, materials science, catalysis, nanoscience, luminescent sensors, medicine. 


\section{SARRERA}

Zientzia eta teknologiak gaur egungo gizarte modernora bidean egin dituen ekarpenak ukaezinak dira. Gizartean sortzen diren galdera edo arazoei irtenbidea bilatzeko grinak, mundua ulertu nahiak edota gauza berriak aurkitzeko gogoak bultzatzen du zientzialaria ikerketan aritzera. Zentzu horretan, Juan Jose (Logroño, 1754) eta Fausto (1755) Elhuyar anaien aurkikuntza, zalantzarik gabe, Euskal Herrian zientziaren arloan egin den ekarpen garrantzitsuena eta unibertsalena dela baiezta genezake. Elhuyar anaiek 1783. urtean Euskalerriaren Adiskideen Elkarteak eraikitako Bergarako Errege Mintegian wolframioa (W), taula periodikoko 74. elementua, lehen aldiz isolatzea lortu zuten. Wolframioak, taula periodikoko gainontzeko metalekin alderatuta, baditu zenbait errekor: i) fusio-puntu altuena duen metala da $\left(\approx 3.400{ }^{\circ} \mathrm{C}\right)$; ii) izaki bizidunen metabolismoan beharrezkoa den elementuen artean astunena da; eta iii) bere karburoaren gogortasuna ia diamantearenaren parekoa da. Horrela, metal hau mundu guztian zehar erabiltzen da boligrafoen puntetan edo bonbillen filamentuetan [1] Elementu kimiko berri bat aurkitzeaz gain, Elhuyar anaiak kimika ez-organikoaren alorrean garrantzi handia izango zuen arlo baten aitzindari izango ziren oharkabean: Polioxometalatoak (1. irudia).
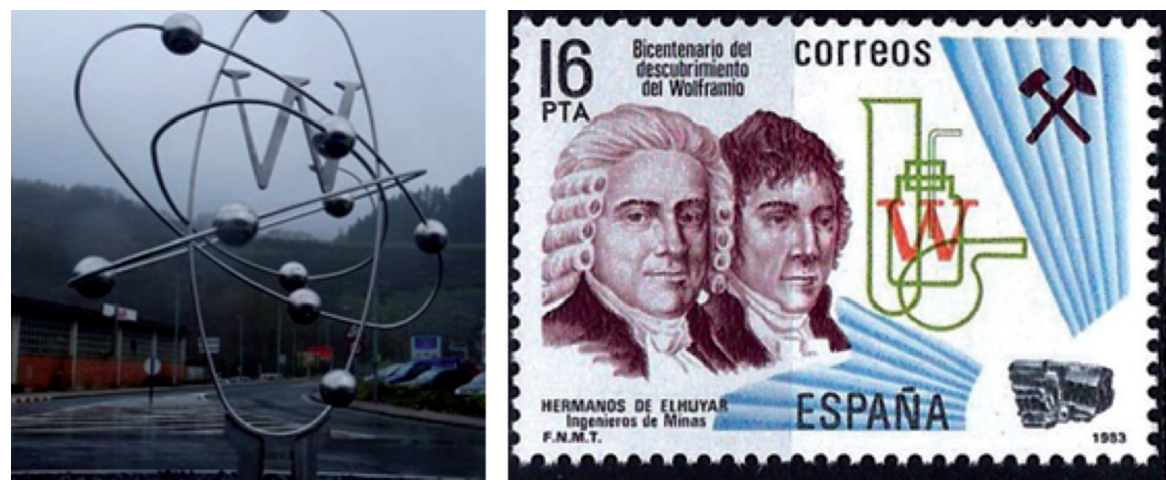

1. irudia. Ezkerraldean Bergarako Amillaga errotondan wolframioaren aurkikuntzaren omenez eraikitako monumentua. Eskuinaldean Elhuyar anaien aurkikuntzaren 200. urteurrenean diseinatutako zigilua.

PoliOxoMetalatoak metalez eta oxigenoz osatutako kluster (atomo talde nanometrikoak) anionikoak dira [2]. Konposizio, egitura eta propietate elektronikoen aldetik duten aniztasun izugarriaren ondorioz, POMek aplikazio esparru zabala dute, besteak beste, katalisia, materialen zientzia, nanoteknologia eta biomedikuntzaren munduan. Nazioartean, 1826. urtean lehen aldiz POM bat $\left(\left(\mathrm{NH}_{4}\right)_{3}\left[\mathrm{PMo}_{12} \mathrm{O}_{40}\right]\right.$ gatza) sintetizatu zuen ikertzailea 
Polioxometalatoak: Elhuyar anaien ametsak bizirik dirau!

J. J. Berzelius izan zela esan ohi den arren, Elhuyar anaiek ia 40 urte lehenago prestatua zuten wolframioan oinarritutako $\left(\mathrm{NH}_{4}\right)_{10}\left[\mathrm{H}_{2} \mathrm{~W}_{12} \mathrm{O}_{42}\right] \cdot 10 \mathrm{H}_{2} \mathrm{O}$ gatza, «hori koloreko konposatu mingots eta mina» bezala deskribatu zutena [3]. Ordutik, nahiz eta 1933. urtean J. F. Keggin-ek $\mathrm{H}_{3}\left[\mathrm{PMo}_{12} \mathrm{O}_{40}\right]$ azidoaren egitura kristalinoa ebatzi, Xx. mendearen bukaera arte POMen kimika ez zen mundura zabaldu. Ordura arteko lan guztien lehen berrikusketa sistematikoa 80ko hamarkadakoa baino ez da [2]. Hala ere, azken 30 urteotan nazioarteko zientzia-argitaletxe eta -aldizkari garrantzitsuenetan argitaratutako liburu eta ale monografikoen kopuruak adierazten du polioxometalatoen kimika gaur egungo kimika ez-organikoaren alorreko arlo dinamikoenetako bat dela [4].

POMak oxidazio egoera altuenean dauden 5. eta 6. taldeetako trantsiziometalez (M) osaturik daude, non ohikoenak banadioa (V), molibdenoa (Mo) eta wolframioa $(\mathrm{W})$ diren. Egiturari dagokionez, POMak $\mathrm{MO}_{x}$ unitate poliedrikoen kondentsazioaren ondorio dira, non $x$ (zentro metalikoaren koordinazio-zenbakia, hots, atomo zentrala inguratzen duen atomo kopurua) 4 eta 7 bitartekoa izan ohi den eta oktaedrikoa (6) geometria arruntena. $\mathrm{MO}_{x}$ unitateak erpinak edo ertzak partekatuz elkartu ohi dira, betiere ahalik eta oxigeno gutxien libre uzten saiatuz, klusterraren disoziazioa ekiditeko (2. irudia). Nolanahi ere, kondentsazio prozesu hau ez da infinitua: zentro metalikoen d orbital huts eta eskuragarriek metal-oxigeno lotura bikoitz terminalen eraketa ahalbidetzen dute eta oktaedro berriekin elkartzea eragozten dute.

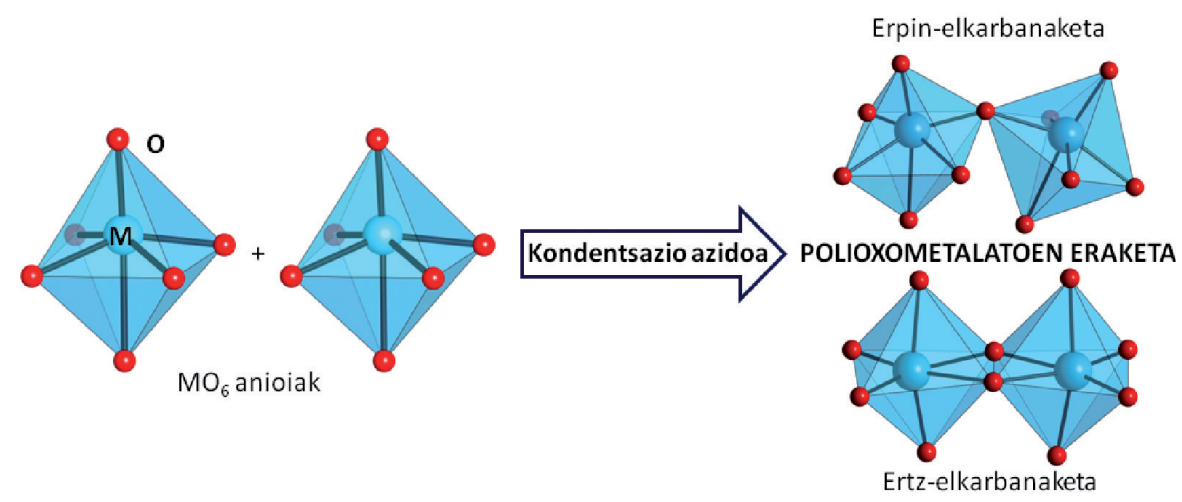

2. irudia. Polioxometalatoen eraketa disoluzioan dauden $\mathrm{MO}_{6}$ unitateen kondentsazio azidoan oinarritzen da. Oktaedroen arteko lotura erpinen edo ertzen elkarbanaketaren bidez gertatzen da normalean.

Konposizioa aintzat hartuta, POM-ak bi talde nagusitan bana daitezke:

a) Isopolioxometalatoak, $\left[\mathrm{M}_{m} \mathrm{O}_{y}\right]^{q-}$ formula orokorrarekin adieraz daitezkeenak, hots, metalez eta oxigenoz soilik osatuta daudenak. 
Adibide adierazgarrienen artean, $\mathrm{M}_{6} \mathrm{O}_{19}$ hexametalato (Lindqvist egitura) edo $\mathrm{M}_{10} \mathrm{O}_{28}$ dekametalato anioiak aurki ditzakegu (3. irudia, ezkerraldean, goiko aldea).

b) Heteropolioxometalatoak, $\left[\mathrm{X}_{x} \mathrm{M}_{m} \mathrm{O}_{y}\right]^{\mathrm{q}-}$ formula orokorrarekin azal daitezkeenak, hau da, metalaz eta oxigenoaz gain heteroatomo (X) deritzen elementu gehigarriak dituztenak. Gas nobleak izan ezik, taula periodikoko edozein elementu izan daiteke heteroatomoa. Adierazgarriak dira i) Anderson-Evans anioia $\left[\mathrm{XM}_{6} \mathrm{O}_{24}\right]^{n-}$, heteroatomo oktaedrikoak dituena ( $\mathrm{X}=\mathrm{Cr}, \mathrm{Mn}, \mathrm{Fe}, \mathrm{In})$; ii) Keggin anioia $\left[\mathrm{XM}_{12} \mathrm{O}_{40}\right]^{n-}$, heterotalde tetraedrikoak dituena $(\mathrm{X}=\mathrm{B}, \mathrm{Si}$, $\mathrm{Ge}, \mathrm{P})$; eta iii) Wells-Dawson anioia $\left[\mathrm{X}_{2} \mathrm{M}_{18} \mathrm{O}_{62}\right]^{n-}$, Keggin anioiaren egituratik eratorritakoa eta bi heteroatomo tetraedriko dituena $(\mathrm{X}=\mathrm{P}, \mathrm{As})$. (3. irudia, eskuinaldean, goiko aldea).

Bereziki molibdenoan oinarritutako zenbait klusterrek metodo kimiko, fotokimiko edo elektrokimiko bidezko erredukzio prozesuak jasan ditzakete, eta (V) / (VI) balentzia mistoko anioi «urdinak» $\left(\mathrm{Mo}^{\mathrm{V}}\right.$-aren kolorea) lortu. Esfera edo kapsula itxurako konposatu hauek 368 zentro metaliko arteko kluster erraldoi diskretuak osa ditzakete. Hala ere, nahiz eta kon-

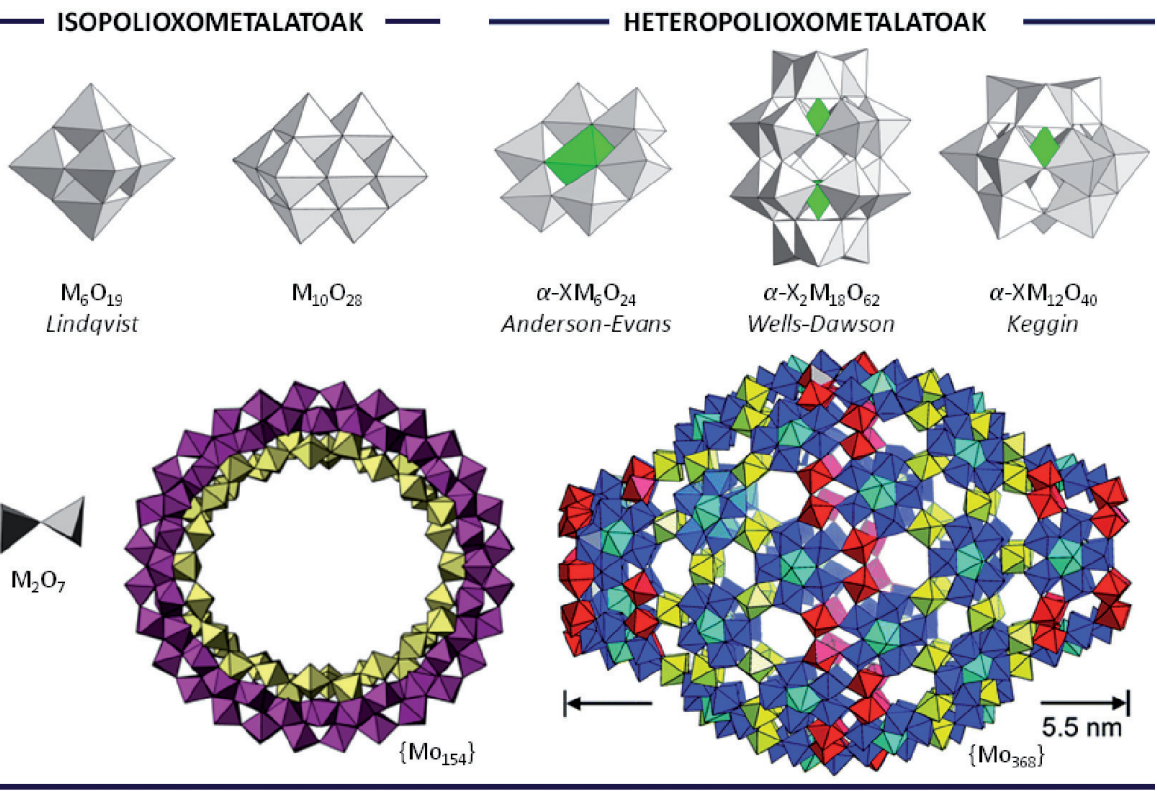

3. irudia. Polioxometalatoen egituren aniztasun ikaragarriaren isla. Kluster ohikoenen egitura molekularraren errepresentazio poliedrikoak eta berauen sailkapena iso- edo heteropolioxometalato bezala. Kolore-kodea: $\mathrm{MO}_{x}$ oktaedro grisak; $\mathrm{XO}_{x}$ poliedro berdeak; espezie «urdinetako» Mo atomo desberdinetako bakoitza kolore ezberdin batez adierazi da. 
Polioxometalatoak: Elhuyar anaien ametsak bizirik dirau!

plexutasun kimiko izugarria izan, anioi hauek $\mathrm{MoO}_{x}$ unitateen autoantolakuntzaren ondorio baino ez dira [5]. Aipatzekoa da, ildo berean, duela zenbait mende Indiar Amerikarrek gaur egungo Alaska edo Colorado inguruko zenbait parke naturaletan atzemandako «ur urdin naturalen» kondairaren jatorriak molibdenoaren erredukzio prozesuarekin duen erlazioa. Laburbilduz, esan genezake POMen egituren aniztasun ikaragarria $\mathrm{M}_{2} \mathrm{O}_{7}$ dimetalatoak bezalako anioi sinple eta txikietatik proteinen tamaina duten kluster konplexuetara doala (3. irudia).

\section{ERABILERAK}

Polioxometalatoekin erlazionatutako 1.000 patentetik gora aurki ditzakegu datu-base zientifikoetan. Ondorioz, ukaezina da POMen aplikazioek zientzia eta teknologiaren munduan duten garrantzia, bereziki katalisia, magnetismoa, materialen zientzia, nanoteknologia eta biomedikuntza bezalako alorretan (4. irudia).

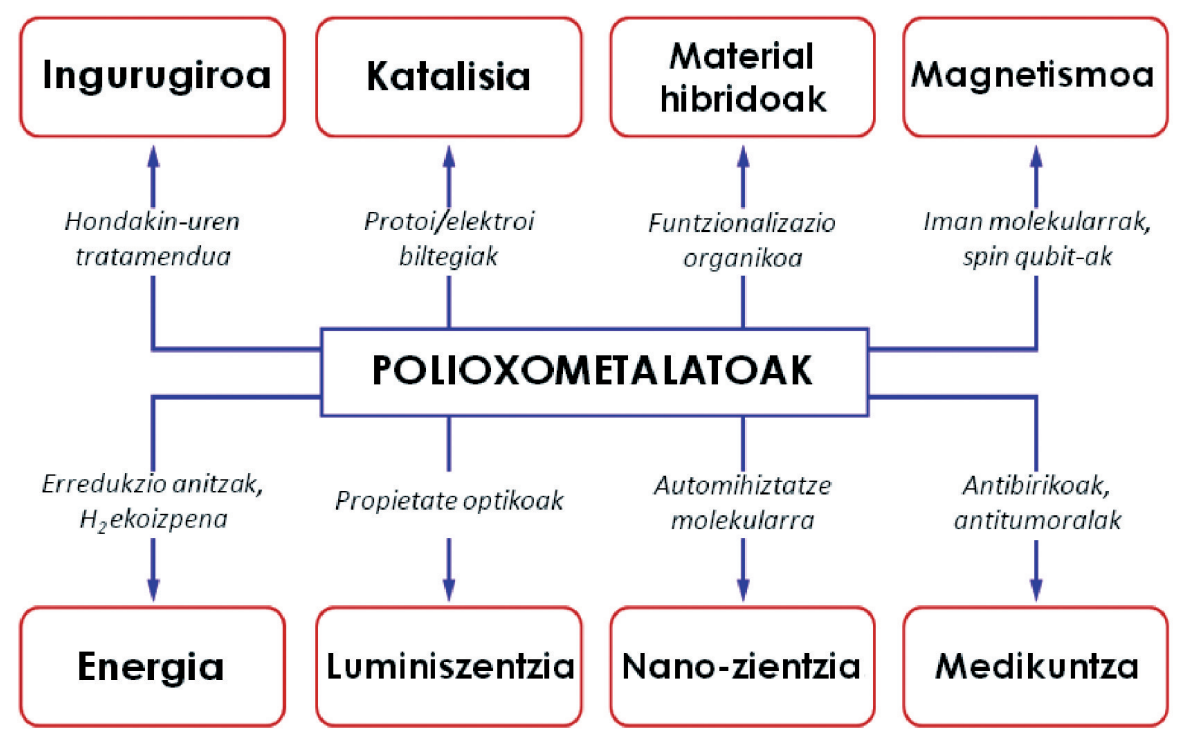

4. irudia. Polioxometalatoen aplikazio esparru zabala agerian jartzen deneko diagrama.

\subsection{Katalisia eta energia-iturri berriztagarriak: aplikazio komertzialetik fotosintesi artifizialera}

Bereziki prozesu katalitikoetan, hots, erreakzio kimikoen abiadura handiagotzen edota etekin eta selektibitatea areagotzen duten eraldaketa kimi- 
Beñat Artetxe, Santiago Reinoso, Juan M. Gutiérrez-Zorrilla

koetan, espezie aktibo gisa erabiltzen dira POMak. Katalizatzaileak erabiliz, erreaktiboak eta energia aurrez daitezke sarritan. Protoien eta elektroien bilgune itzulgarri izateko duten ahalmenari esker (protonazio/desprotonazio prozesuei loturiko erredukzio/oxidazio itzulgarriak jasan ditzakete), kluster hauek sarri aurki daitezke katalizatzaile azido bezala edo oxidazioerreakzio katalitikoetan.

Adibide gisa, azpimarragarria da heteropoliazidoen erabilera industrial katalitikoa gas egoeran dauden azido azetiko eta etilenotik hasita, etil azetatoa (tinta, farmako eta estalduren industrian oso erabilia den disolbatzailea) pauso bakarrean ekoizteko prozesuan. AVADA (ingelesez AdVanced Acetates by Direct Addition) deritzon prozesu industrial hau 2001. urtean ezagutarazi zen Hullen, Erresuma Batuan British Petroleum-ek (BP) eraikitako munduko etil azetato ekoizpen-planta handienarekin (220.000 Tn/ urte). 2011n Europan kontsumitu zen etil azetatoaren \% 56 ekoiztu zen planta honetan, eta 340 milioi dolarreko irabazia eskuratu zen. Gainera, prozesuak baditu zenbait abantaila ingurugiroari dagokionez, kontsumo energetikoaren \% 20 eta ekoiztutako hondakinen \% 35eko murrizketa eragiten baitu. Eskalatze industrialak ingeniaritza eta kimika berdearen arloetan bikaintasuna ziurtatzen duen AstraZeneca sari entzutetsua jaso zuen. Katalizatzaile azidoa salgai dago munduko produktu kimikoen hornitzaile ohikoenetan, eskaintzen dituen iraunkortasunari eta abantaila ekonomikoei esker.

Aplikazio katalitiko hutsetik haratago, POMek erlazioa dute gaur egungo energia-iturri berriekin. Energia berriztagarrien produkzioa XXI. mendeko erronka handienetako bat da. Horregatik, erregai fosilen ordezkoa bilatu nahian, Lur planetaren energia-iturri nagusia (hau da eguzkia) erabiltzea da gure zientzialari garaikideen helburu nagusienetariko bat. Simulatu nahi den prozesuetako bat landareen fotosintesia da, non argi modura jasotzen den energia, energia kimiko bihurtzen den. Eguzkitik datorren argia erabiliz $\mathrm{CO}_{2}$ eta $\mathrm{H}_{2} \mathrm{O}$ erreaktiboak, laborategian karbohidrato eta $\mathrm{O}_{2}$ bilakatzeko prozesuari, fotosintesi artifiziala deritzo. Teknologia hau erakargarria da ikuspuntu praktiko, ekonomiko eta ekologikotik, energia iturria izateaz gain, erregai fosilen errekuntzatik sortzen diren zenbait arazo (berotegi efektua kasu) arintzeko baliagarria izango bailitzateke. Hala ere, fotosintesi prozesua hain da konplexua (erreakzio ezberdinak katalizatzen dituzten hamaika entzimek hartzen dute parte) ezen momentuz oso zaila baita laborategian errepikatzea. Beraz, fotosintesi artifiziala bi fase nagusitan ikertu ohi da laborategian: 1) fase argitsuan gertatzen den uraren disoziazioa oxigeno eta hidrogeno gasak lortzeko; 2) fase ilunean gertatzen den $\mathrm{CO}_{2}$-aren finkapena.

Batetik, uraren disoziazioa POM bidezko erreakzio fotokatalitiko bidez lor daiteke. Etorkizuneko erregaitzat hartzen den $\mathrm{H}_{2}$ gasa lortzeko (erregaipiletan oinarritutako teknologia bidez lor daiteke energia) gaur egun erabil- 
Polioxometalatoak: Elhuyar anaien ametsak bizirik dirau!

tzen diren metodoek energia-ekarpen handia behar dute. Aldiz, erreakzio fotokatalitikoa ekoizpenerako metodo garbi eta eraginkorrenetako bat litzateke, hauts erako katalizatzaile heterogeneoa uretan esekiduran mantentzea baino ez litzatekeelako behar. Azpimarratzekoa da testuinguru honetan, Weakley motako $\left[\mathrm{Co}_{4}\left(\mathrm{H}_{2} \mathrm{O}\right)_{2}\left(\mathrm{PW}_{9} \mathrm{O}_{34}\right)_{2}\right]^{10-}$ anioiaren eraginkortasuna, askoz garestiagoak diren rutenioan oinarritutako konplexuek baino emaitza hobeak ematen baititu (5. irudia). Era berean, kluster honek, beste katalizatzaile askok ez bezala, egonkortasuna (hidrolitikoa eta oxidatiboa) eta lan egiteko $\mathrm{pH}$ tarte zabala ditu, baita fase homogeneoan lan egiteko aukera ere [6]. Bestetik, nahiz eta POM bidezko $\mathrm{CO}_{2}$-aren finkapena ez den horrenbeste ikertu, adibide garrantzitsuak aurki daitezke bibliografian [7].

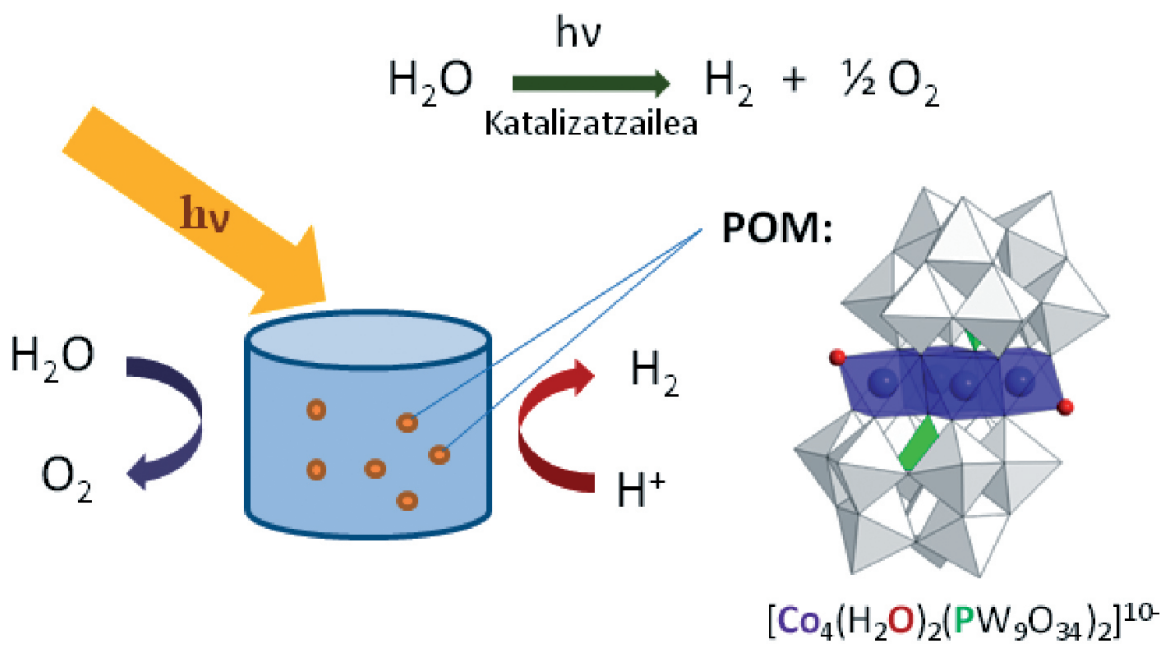

5. irudia. Uraren fotodisoziazio katalitikoaren eskema orokorra eta Weakley motako POMaren egitura molekularra.

\subsection{Gasen harrapaketa eta hondakin-uren tratamendua}

Porositate handiko material kristalinoek betidanik erakarri dute zientzialarien interesa molekula ostalariak harrapatzeko, ioi-trukea gauzatzeko edota katalizatzaile heterogeneo bezala jokatzeko duten ahalmenagatik. Konposatu hauetako asko, gai dira tamainaren araberako espezieak diskriminatzeko eta bahe molekular baten lana egiteko konposatu ezberdinen banaketa prozesuan. Polioxometalatoak bezalako makroanioi eta makrokatioi molekularren arteko kristal ionikoek, hutsune asko uzten dituzte eskuragarri, beraien tamaina eta forma bereziek paketatze eraginkorra zailtzen baitute. Hurbilketa sintetiko hau jarraituz, Keggin motako $\left[\mathrm{XW}_{12} \mathrm{O}_{40}\right]^{n-} \mathrm{POMez}$ eta $\left[\mathrm{Cr}_{3} \mathrm{O}(\mathrm{OOCH})_{6}\left(\mathrm{H}_{2} \mathrm{O}\right)_{3}\right]^{+}$unitatez eratutako konposatuak gai dira kate alifatikoan karbono bakarreko ezberdintasuna duten gas zein likido egoe- 
rako molekula polarrak (alkohol, nitrilo eta esterrak) era eraginkorrean banatzeko absortzio selektiboaren bidez. Gainera, formiatoaren $\left({ }^{-} \mathrm{OOCH}\right)$ ordez talde handiagoak dituzten karboxilatoen erabilerak (adibidez, propanoatoa $-\mathrm{OOCC}_{2} \mathrm{H}_{5}$ edo butanoatoa $-\mathrm{OOCC}_{3} \mathrm{H}_{7}$ ) bahe molekular gisa jokatzeko ahalmena alkeno edo haloalkanoak bezalako konposatu apolarragoetara heda dezake [8].

Egitura porotsuekin jarraituz, mundu mailan tradizionalki erabili izan diren zeolita edo ikatz aktiboen ordezko bezala aurkeztu dira polimero metal-organikoak (ingelesez, Metal-Organic Frameworks). MOFak atomo emaileak dituzten molekula organiko (estekatzaile) eta ioi metalikoz eratutako koordinazio-sareak dira. «Esponja molekular» hauen azalera hain da handia ezen konposatu gramo batek 7000 metro karratuko barne-azalera, hots, zortzi tenis zelairen pareko gainazala, izan baitezake [9]. Dena den, egitura hauek duten sendotasun-faltak (egonkortasun termiko eta estruktural eskasa dute sarritan) berauen erabilera praktikoa mugatu egiten du. Egonkortasuna handitu eta erreakzio-baldintza leunagoak erabili nahian, ikertzaile askok polioxometalatoetan oinarritutako MOFerako konposatuak (POMOFak) prestatu dituzte [10]. Gainera, POMek berezkoak dituzten propietateak (katalisian edo elektroi-biltegi modura jokatzeko ahalmena, adibidez) gehitzen dizkiote aipatutako egitura porotsuari. Mota honetako konposatuekin garrantzi handiko lanak egin dira ingurugiroarekin erlazioa duten gaietan. Bereziki, gas toxikoak bahitzeaz gain, POMOFak gai dira toxikoak edo kaltegarriak diren gas edo konposatu organiko lurrunkorren deskonposizioa eragiteko, POMen propietate katalitikoak aprobetxatu eta kaltegarriak ez diren erreakzio produktuak lortuz. Besteak beste, erregai fosiletan agertzen diren sufredun konposatu kaltegarrien $\left(\mathrm{H}_{2} \mathrm{~S}\right.$, merkaptanoak...) oxidazioa era errazean gerta daiteke POMOF baten barnean oxidatzaile gisa aireko $\mathrm{O}_{2}$-a erabiliz. Azkenik, gizakion nerbio-sistema zentralean eragina duen dimetil metilfosfonatoaren (gizakion heriotza eragin dezakeen arma kimikoa, sarin gasarekin erlazionatutakoa) fotolisia ere gauzatu daiteke aipatutako sare molekularren muinean.

POMek ingurugiroarekin erlazioa duten gaietan dituzten aplikazioak ez dira POMOF erako egiturak dituzten konposatuetara mugatzen. Esaterako, hondakin erreaktiboen desaktibaziorako erreminta baliagarri bezala ikertu dira askotan, teknezio, uranio edo neptunio katioiei lotzeko duten afinitate handia aprobetxatuz [11]. Hondakin-uren tratamenduari dagokionez, hainbeste industriatan erabiltzen diren koloratzaile eta pestiziden oxidazio heterogeneo katalitikoan sarri hartzen dute parte, baina baita konposatu kutsagarrien analisian ere. Oraintsu argitaratutako lan batean frogatu da lur arraroak dituzten $\left[\mathrm{Ln}_{4}\left(\mathrm{H}_{2} \mathrm{O}\right)_{6}\left(\mathrm{GeW}_{10} \mathrm{O}_{38}\right)_{2}\right]^{12-}$ anioiak $(\mathrm{Ln}=\mathrm{Dy}, \mathrm{Ho}$, $\mathrm{Er}, \mathrm{Tm}$ ) hondakin-ur industrialetan agertzen den konposatu kaltegarri eta arruntenetako baten (anilina) oxidazioa ingurune-tenperaturan kataliza- 
Polioxometalatoak: Elhuyar anaien ametsak bizirik dirau!

tzeko gai direla. Prozesua guztiz selektiboa da, \% 100ean nitrosobentzenoa lortzen baita produktu gisa. Bide berde $\left(\mathrm{H}_{2} \mathrm{O}_{2}\right.$ bidezko oxidazio katalitikoan ura da sortzen den azpiproduktu bakarra), garbi eta merke honetan, kutsatzaile bat eliminatzen da eta industria ezberdinetarako baliagarria den lehengaia lortzen da [12]. Ildo beretik jarraituz, kutsatzaileak desagerraraztea baino are garrantzitsuago da hauen erabilera ekiditea. Ildo honetan, kloroan oinarritutako konposatuen ordezko «berde» bezala aurkeztu da $\left[\mathrm{AlVW} \mathrm{W}_{11} \mathrm{O}_{40}\right]^{6-} \mathrm{POM}$ anioia, papergintzan, zuritzearekin lotutako egurraren deslignifikazio prozesurako [13].

\subsection{Fotolumineszentzia, sentsore kimikoei begira}

Zenbait material gai dira gizakiontzat ikusezina den argia (energia handiko argi ultramorea, normalean) xurgatu, beraien egitura elektronikoa kitzikatu eta oinarrizko egoera energetikora bueltatzeko. Desaktibazio prozesu honetan argi ikuskor edo infragorria igortzen duten sistemak fotolumineszenteak direla esaten da. Lantanidoak (lur arraroak) propietate lumineszenteen ohiko erantzuleak izaten dira kimika ez-organikoaren arloan. Arrunta da samario ( $\mathrm{Sm}$ ), europio (Eu), terbio (Tb) edo disprosio (Dy) espezieen argi laranjaren, gorriaren, berdearen edo horiaren igorpena, hurrenez hurren. Hala ere, ezinbestekoa da ioi metaliko hauentzat «antena» gisa jokatu eta argi ultramorea xurga dezaketen estekatzailez inguratzea. Sistema aromatiko $\pi$-konjokatuak azaltzen dituzten molekula organikoez gain, POMek ere antena lana egin dezakete, eta kolore zehatzeko eta distira handiko igorpenak lortu [14]. Propietate fotofisiko hauek dituzten materialek erabilera teknologiko anitzak aurki ditzakete, besteak beste analisi biomedikoetan, zelula fotovoltaikoetan, transistore optikoetan, laserretan, edota LED diodoetan.

Fenomeno orokor horrez gain, argi-igorpena inguruko espezieren batekiko elkarrekintzan oinarrituta dagoenean, sentsore kimiko baten aurrean gaudela esan genezake. Hau da, POMak sare porotsu baten osagai direnean, edota polimero organikoak bezalako anfitrioietan aurkitzen direnean, molekula ostalari ezberdinen presentziak propietate fotofisikoen aldaketa eragin dezake bai igorpenaren kolorean, bai beronen intentsitatean. Muturreko adibide garbitzat har dezakegu berriki argitaratutako selektibitate handiko $\mathrm{CO}_{2}$ sentsorea. [15] Metakrilatotan bahitutako $\left[\mathrm{DyW}_{10} \mathrm{O}_{36}\right]^{9-}$ anioiek ez dute lumineszentziarik beraien kabuz. Aldiz, $\mathrm{CO}_{2}$ gasaren presentzian, beronen kontzentrazioarekiko proportzionala den intentsitatea duen argia igortzen du POMak (6. irudia). Ondorioz, $\mathrm{CO}_{2}$-aren detekziorako ez ezik, kuantifikaziorako ere erabil daitekeen sistema baten aurrean gaudela esan genezake. Beste metodo tradizional batzuekin alderatuz, sentsore hauen abantaila begi bistaz antzeman daitekeen bat-bateko aldaketa bortitzean egon liteke. 


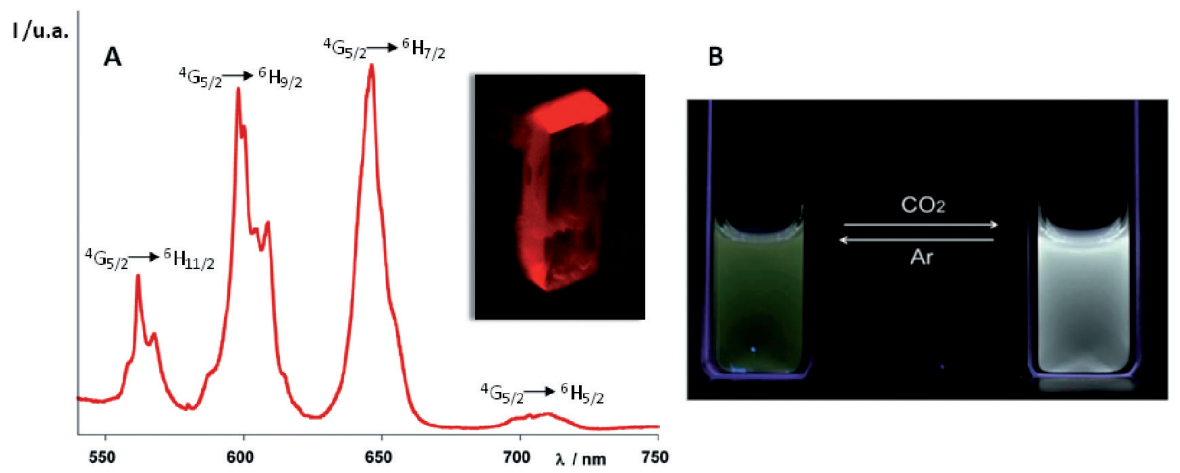

6. irudia. A) $\mathrm{Sm}^{3+}$ ioiak dituen POM baten igorpen-espektroa eta konposatuaren kristal baten argazkia argi ultramoreaz kitzikatzean. B) Igorpen lumineszentearen aldaketa $\mathrm{CO}_{2}$ gasaren presentziaren arabera (sentsore kimiko lumineszentea).

\subsection{POM magnetikoak: iman molekularrak eta konputazio kuantikoa}

Ordenagailuetako disko gogorra informazio iraunkorra gordetzen duen gailua da. Disko gogorrek datu-kopuru handiak gordetzeko gaitasuna izaten dute eta azkarrak dira datuak bilatzeko, ezabatzeko eta idazteko orduan. Helburu horiek lortzeko asmoz, grabazio-sistema magnetiko-digitala erabiltzen da. Grabaziorako sistemaren oinarri den material magnetikoan, momentu magnetikoen arteko akoplamenduak daude, eta horren ondorioz, momentu magnetikoek norabide berean lerrokatzeko joera dute. Hori dela eta, energia minimizatzeko, materialetan zenbait mikrometroko domeinuak, hots, momentu magnetikoen orientazio bera duten eskualdeen pilaketak, agertzen dira. Domeinu magnetiko hauek gai dira informazioa gordetzeko imanazioaren orientazioaren arabera. Ondorioz, zenbat eta domeinu magnetiko txikiagoak izan, material magnetikoaren masa/bolumen unitateko informazio gehiago gordetzeko gai izan beharko ginateke. Ildo honetan, muturreko kasua da iman molekularren erabilera konputazio kuantikoaren garapenean.

Iman molekularren kasuan, nanometro gutxi batzuetako molekula bakar bat (domeinu magnetiko ñimiñoena baino 1.000 aldiz txikiagoa) gai da imanazio iraunkorra aurkezteko. Bide berean, lantanidoen (anisotropia magnetiko eta oinarrizko egoerako espinaren balio altua) eta POMen arteko konbinazioa magnetizazioaren erlaxazio geldoa (iman molekularrak) duten sistemak prestatzeko bide ezin hobea dugu. Estekatzaile gisa jokatzen duten bi POM unitateen artean lantanido katioi bakarra duten Peacock-Weakley motako $\left[\mathrm{LnW}_{10} \mathrm{O}_{36}\right]^{9-}$ (non $\mathrm{Ln}=$ lantanido ioia) egiturak dira POM familia hauen adibide esanguratsuena (7. irudia) [16]. Kasu hauetan, nanoimanen miniaturizazioaren mugara irits gaitezke, zentro magnetiko bakarra (lantanido ioia) baita propietate magnetikoen erantzulea. Horrez guz- 
Polioxometalatoak: Elhuyar anaien ametsak bizirik dirau!

tiaz gain, sistema hauek espintronikaren barnean eta konputazio kuantikora bidean garrantzi handiko papera joka dezakete etorkizunean. Espin egoeretako bakoitza $(1 / 2,-1 / 2)$ gai izango litzateke kodigo bitarreko 0 eta 1 egoerak errepresentatzeko, eta beraz, ohiko bit unitateen ordez, bit kuantiko edo «qubit»etan oinarritutako teknologia berri baten aurrean geundeke [17]. Azpimarragarria da zentzu honetan, 2014. urtean garatu zen POM klusterretan oinarritutako flash memorien teknologia [18].

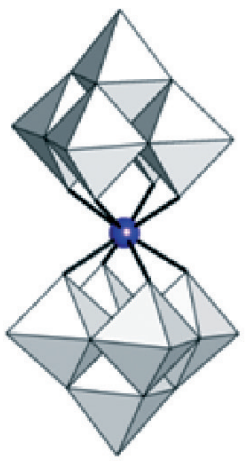

$\left[\operatorname{Ln}\left(\mathrm{W}_{5} \mathrm{O}_{18}\right)_{2}\right]^{9-}$

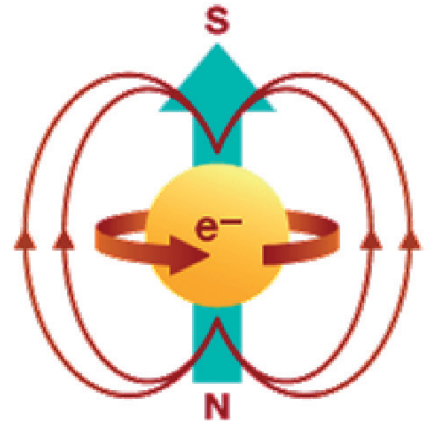

1

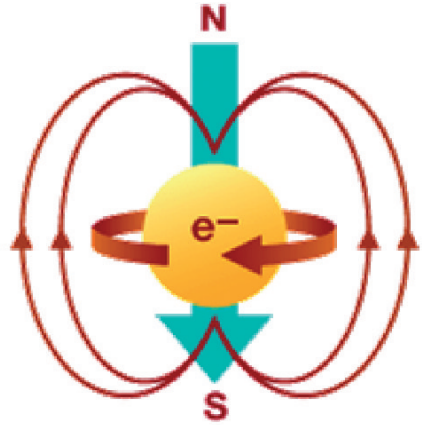

0

7. irudia. Peacock-Weakley motako klusterren egitura molekularra (ezkerraldean) eta espin egoera ezberdinen eta kodigo bitarren arteko lotura (eskuinaldean).

\subsection{Nanozientzian barrena: masusta itxurako egiturak eta biologia ez-organikoa}

Azken urteotan horren entzutetsua bilakatu den nanozientziaren helburua da nanometro $\left(10^{-9} \mathrm{~m}\right)$ mailako sistemen ulermena, nanoteknologiaren bitartez berauek aldatzen eta kontrolatzen saiatzen dena. Sistema nanometrikoen ezaugarri garrantzitsuenetako bat automihiztatzeko aukera da, hots, gizakiaren eraginik gabe egiturek berrantolatu, konpondu edota sistema berriak sortzeko duten ahalmena. Automihiztatzearen ikerketa hain da garrantzitsua ezen bizitzaren jatorriari buruzko galdera askoren funtsa baita, besteak beste, proteinen paketatze prozesuan edota zelulen banaketa egiteko orduan. Kimika sintetikoaren alorrean, molekula asko gai dira espontaneoki beraien artean elkartzeko eta tamaina handiagoko egitura «supramolekularrak» eratzeko.

Beraien egonkortasuna, karga negatibo altua eta disolbagarritasuna dela-eta, tamaina handiko POMek (2-6 nm bitartean) ezohiko portaera dute ur-disoluzioan. Klusterren arteko automihiztatzeak «masusta itxurako» egitura supramolekular esferikoak sortzen ditu, hau da, karga bereko espezieak barnealdetik hutsak diren egitura besikularretan antolatzen dira [19] 
(8. irudia). Izaera besikular honek, farmakoen askapen kontrolaturako sistema bezala ikertzea eragin du. Eraikuntza hauek makroanioien eta katioien arteko tamaina ezberdinean oinarritzen dira, eta beraz, katioi txikiagoekin klusterrek duten elkarrekintzak ahalbidetzen du karga bereko espezieak elkarrengandik hain hurbil mantentzea. Masusta itxurako egituren eraketa parametro esperimentalen bidez kontrola daiteke, besteak beste, ingurunearen $\mathrm{pH}-\mathrm{a}$, erabiltzen den disolbatzailearen polaritatea, surfaktante kationikoen adizioa etab. Gainera, egitura esferiko besikularrek, zenbait antzekotasun dituzte sistema biologikoekin alderatzean. Esaterako, kapsida biralen egiturak eta eraketa prozesuaren zinetikak erlazio handia dute masusta itxurako egiturek azaltzen dutenarekin. Bestalde, bizitzarekin erlazionatutako prozesuek berezkoak dituzten propietate ikusgarriak azal ditzakete egitura supramolekular hauek. Horien artean txundigarriena da egituren eraketan zehar klusterrek duten elkar ezagutzeko ahalmena. Berdintsuak diren bi POMen nahastetik, homogeneoak diren masusta itxurako egiturak, hots, kluster berdin-berdinez eratutakoak, bakarrik lortzen dira eta inoiz ez POM ezberdinen nahasketaz eratutakoak [20].

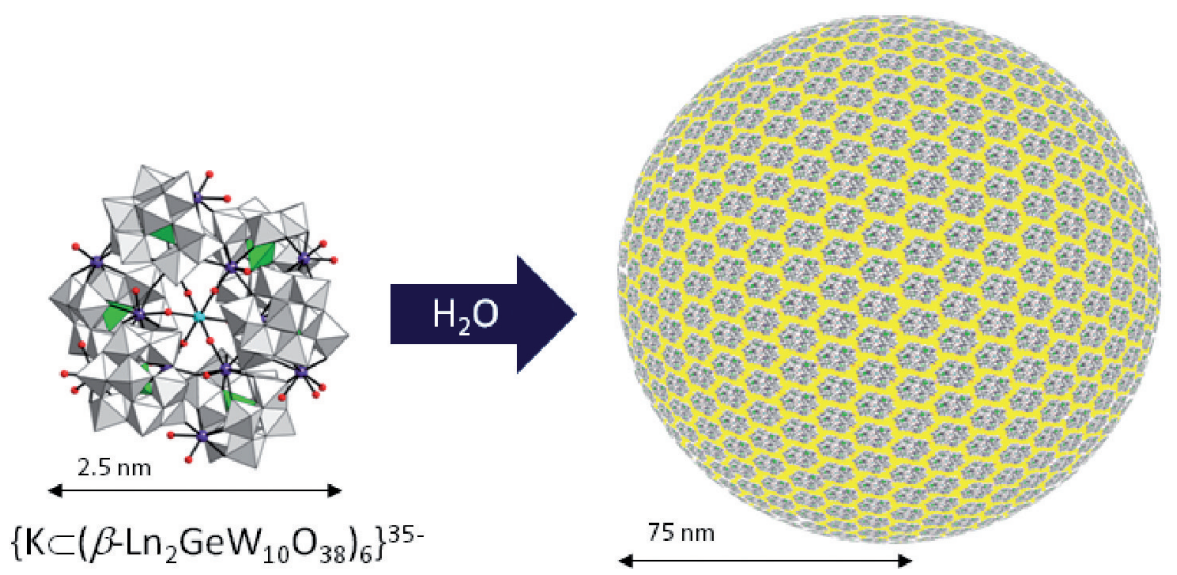

8. irudia. Masusta itxurako egituren eraketa kluster makroioniko diskretuen automihiztaduraren ondorio da disolbatzaile polarretan.

Bestalde, aspaldi honetan Glasgow-ko Unibertsitatean egiten ari diren lanak bizitzaren inguruko zenbait paradigma zalantzan jartzen ari dira. Lur planetako bizi guztia biologia organikoan oinarrituta dago, hau da, karbonoa eta beste elementu batzuekin elkartzean beronek era ditzakeen aminoazido, azukre, nukleotido etab.etan. Aldiz, mundu ez-organikoa, bizigabeko arloekin lotuta dagoena dela kontsideratu ohi da. Pentsaera hau aldatzeko asmoz eta bizitza eboluzioa jasan dezakeen edozein sistema bezala definituz, Eskoziako ikertzaileak gai izan dira erreplikatzeko ahalmena duten 
Polioxometalatoak: Elhuyar anaien ametsak bizirik dirau!

zelula ez-organikoak sintetizatzeko, eta «biologia ez-organikoa» deritzon zientziaren atalari atea irekitzeko. Zelula ez-organikoak zenbait materialekiko iragazkorrak diren mintzez inguratuta daude eta gai dira beraien barnean prozesu kimikoak gauzatzeko ohiko zelula biologikoek egiten duten antzera. Medikuntzaren munduan edota erreaktore kimiko gisa izan dezaketen erabileraz gain, ikertzaileek diote helburua zelula kimiko konplexuak sortzea dela, zeinak gai izan daitezkeen bizitzaren jatorriaren inguruko galderei buruzko erantzunak bilatzeko. Beraien hitzetan, lorpen honek eboluzio biologikoari buruz gizarteak duen ikuspuntua alda dezake eta karbonoan oinarritzen ez den bizieraren bati aukera eman diezaioke [21].

\subsection{Biomedikuntza: Alzheimerraren eta minbiziaren aurkako erremedioa ote?}

Cis-platinoaren minbiziaren kontrako aktibitatea ezagutu zenetik, farmako ez-organikoen kopurua eta beraien inguruko ikerketa izugarri hazi da azken urteotan. Ildo berean, aspaldidanik ezagunak dira POMen propietate bioaktiboak. Besteak beste, emaitza onak aurkeztu dituzte proteasen inhibitzaile modura HIESaren tratamenduan edota minbizi kasu batzuetan (bularreko minbizian, adibidez) gainespresatuta agertzen den Sox2ren eta DNAren arteko lotura ekiditeko orduan. Hala ere, bereziki aipatzekoa da Wells-Dawson erako anioiek Alzheimer gaitzaren eragiletzat jotzen den $\beta$-amiloideen agregazioa eta berauen peroxidasa aktibitatea inhibitzeko erakutsi duten ahalmena. In vivo egindako ikerketek erakusten dute farmakoa muga hematoentzefalikoa zeharkatzeko gai dela eta 48 orduren ostean metabolizatzeko aukera dagoela [22].

Biokimikaren munduan are gehiago murgilduz, proteinen kristalizazioa eta egituren ebazpena oso garrantzitsua izaten da berauen funtzionamendua ulertzeko orduan. Helburu honekin, atomo pisutsuak dituzten gehigarriak erabili ohi dira sarritan eta ildo honetan, zentro metaliko anitzez eraturiko POMek duten erabilgarritasuna ukaezina da. Esaterako, 2009ko Kimikako Nobel Saria erribosomaren egituraren eta funtzioaren inguruan egindako ikerketagatik eman zitzaien V. Ramakrishnan, A. Yonath eta T. A. Steitz ikertzaileei. Lan honetan, klusterretan oinarritutako konposatuez baliatu behar izan ziren, POMak gai baitira elkarrekintza espezifikoen bidez (elektrostatikoa, kobalentea, hidrogeno loturak) proteinen parte konkretu bati lotzeko [23].

\section{ONDORIOAK}

Azken mendean, POM motako egituren inguruko ikerketak aurrerapauso itzelak eman ditu bai konposatu eta egitura berrien sintesian, karakterizazioan eta ebazpenean, bai berauen propietateen ustiapenean esparru 
Beñat Artetxe, Santiago Reinoso, Juan M. Gutiérrez-Zorrilla

oso desberdinetako aplikazioetan. Funtzio anitzekoak izan ohi diren metalez eta oxigenoz eratutako kluster hauetan oinarritutako konposatuei etorkizun oparoa aurreikusten zaien arren, bultzada txiki bezain garrantzitsua espero dute ikerketa aplikatuaren aldetik gizartearen eguneroko bizitzaren parte izan ahal izateko. Sintesiak dituen konposizio-aukera mugagabeak, gaur egun ezagutzen diren aplikazioez gain, lan-esparru berriak ireki ditzakeela uste da. Elhuyar anaien ausazko aurkikuntzatik hona, sekula amestu ezin izango luketen POMen mundua azaldu da. Eta hauek hasierako pausoak baino ez dira; izan ere, Elhuyar anaien ametsak oraindik ere bizirik dirau eta bizirik egoten jarraituko du datozen hamarkadetan ere.

\section{ESKER ONAK}

B.A.k UPV/EHUko ikerketa errektoreordetzak finantzatutako doktorego ondoko laguntza eskertzen du. S.R.k InaMat eta Nafarroako Unibertsitate Publikoaren «Talentua Erakartzeko Programa»ren bidez (Obra Social la Caixa eta Fundación Caja Navarra) jasotako diru-laguntza eskertzen du.

\section{BIBLIOGRAFIA}

[1] GOYA, P., MARTÍN, N. eta ROMÁN, P. 2011. «W for tungsten and wolfram». Nature Chemistry, 3, 336.

[2] POPE, M.T. 1983. Heteropoly and Isopoly Oxometalates. Springer-Verlag, Berlin.

[3] DE LUYART, J.J. eta DE LUYART, F. 1783. «Análisis químico del volfram, y examen de un nuevo metal, que entra en su composición». Extractos de las Juntas Generales Celebradas por la Real Sociedad Bascongada de los Amigos del País en la Ciudad de Vitoria, 46-88.

[4] SÉCHERESSE, F. Ed. 2013. Polyoxometalate Chemistry: Some Recent Trends. World Scientific, Singapur.

[5] MÜLLER, A., BECKMANN, E., BÖGGE, H., SCHMIDTMANN, M. eta DRESS, A. 2002. «Inorganic chemistry goes protein size: a $\mathrm{Mo}_{368}$ nanohedgehog initiating nanochemistry by symmetry breaking». Angewandte Chemie, International Edition English, 41, 1162-1167.

[6] YIN, Q., TAN, J.M., BESSON, C., GELETII, Y.V., MUSAEV, D.G., KUZNETSOV, A.E., LUO, Z., HARDCASTLE, K.I. eta HILL, C.L. 2010. «A fast soluble carbon-free molecular water oxidation catalyst based on abundant metals». Science, 328, 342-345.

[7] KIMURA, T., KAMATA, K. eta MIZUNO, N. 2012. «A bifunctional tungstate catalyst for chemical fixation of $\mathrm{CO}_{2}$ at atmospheric pressure». Angewandte Chemie, International Edition, 51, 6700-6703. 
Polioxometalatoak: Elhuyar anaien ametsak bizirik dirau!

[8] UCHIDA, S. eta MIZUNO, N. 2007. «Design and syntheses of nano-structured ionic crystals with selective sorption properties». Coordination Chemistry Reviews, 251, 2537-2546.

[9] CEPEDA, J. eta PÉREZ-YÁÑEZ, S. 2016 «Funtzio anizteko polimero metal-organiko porotsuak (MOF): etorkizuneko material adimenduei begira». Ekaia, 31, 105-116.

[10] MIRAS, H.N., VILÀ-NADAL, L. eta CRONIN, L. 2014 «Polyoxometalate based open-frameworks (POM-OFs)». Chemical Society Reviews, 43, 56795699.

[11] BURTON-PYE, B.P, RADIVOJEVIC, I., MCGREGOR, D., MBOMEKALLE, I., LUKENS, W.W. eta FRANCESCONI, L.C. 2011 «Photoreduction of ${ }^{99} \mathrm{Tc}$ pertechnetate by nanometer-sized metal oxides: new strategies for formation and sequestration of low-valent technetium». Journal of American Chemical Society, 133, 18802-18815.

[12] TRAUTWEIN, G., EL BAKKALI, B., ALCAÑIZ-MONGE, J., ARTETXE, B., REINOSO, S. eta GUTIÉRREZ-ZORRILLA, J.M. 2015 «Dimeric assemblies of lanthanide-stabilised dilacunary Keggin tungstogermanates: A new class of catalyst for the selective oxidation of aniline». Journal of $\mathrm{Ca}$ talysis, 331, 110-117.

[13] WEINSTOCK, I.A., BARBUZZI, E.M.G., WEMPLE, M.W., COWAN, J.J., REINER, R.S., SONNEN, D.M., HEINTZ, R.A., BOND, J.S. eta HILL, C.L. 2001 «Equilibrating metal-oxide cluster ensembles for oxidation reactions using oxygen in water». Science, 414, 191-195.

[14] YAMASE, T. 2009. «Luminescence of polyoxometallolanthanoates and photochemical nano-ring formation». Handbook on the Physics and Chemistry of Rare Earths, 39, 297-355.

[15] WEI, H., ZHANG, J., SHI, N., LIU, Y., ZHANG, B., ZHANG, J. eta WAN, X. 2015. «A recyclable polyoxometalate-based supramolecular chemosensor for efficient detection of carbon dioxide». Chemical Science, 6, 7201-7205.

[16] CLEMENTE-JUAN, J.M., CORONADO, E. eta GAITA-ARIÑO, A. 2012. «Magnetic polyoxometalates: from molecular magnetism to molecular spintronics and quantum computing». Chemical Society Reviews, 41, 7464-7478.

[17] SHIDDIQ, M., KOMIJANI, D., DUAN, Y., GAITA-ARIÑO, A., CORONADO, E. eta HILL, S. 2016. «Enhancing coherence in molecular spin qubits via atomic clock transitions». Nature, 531, 348-351.

[18] BUSCHE, C., VILÀ-NADAL, L., YAN, J., MIRAS, H.N., LONG, D.-L., GEORGIEV, V.P., ASENOV, A., PEDERSEN, R.H., GADEGAARD, N., MIRZA, M.M., PAUL, D.J., POBLET, J.M. eta CRONIN, L. 2014. «Design and fabrication of memory devices based on nanoscale polyoxometalate clusters». Nature, 515, 545-549.

[19] LIU, T., DIEMANN, E., LI, H., DRESS, A.W.M. eta MÜLLER, A. 2003. «Self-assembly in aqueous solution of wheel-shaped $\mathrm{Mo}_{154}$ oxide clusters into vesicles». Nature, 426, 59-62. 
[20] LIU, T., LANGSTON, M.L.K., PIGGA, J.M., PICHON, C., TODEA, A.M. eta MÜLLER, A 2011. «Self-recognition among different polyprotic macroions during assembly processes in dilute solution». Science, 331, 15901592.

[21] COOPER, G.J.T., KITSON, P.J., WINTER, R., ZAGNONI, M., LONG, D.L. eta CRONIN, L. 2011. «Modular redox-active inorganic chemical cells: iCHELLs». Angewandte Chemie International Edition, 50, 10373-10376.

[22] GAO, N., SUN, H., DONG, K., REN, J., DUAN, T., XU, C. eta QU, X. 2013 «Transition-metal-substituted polyoxometalate derivatives as functional anti-amyloid agents for Alzheimer's disease». Nature Communications, 5, 3422 (1-9).

[23] SCHLUENZEN, S., TOCILJ, A., ZARIVACH, R., HARMS, J., GLUEHMANN, M., JANELL, D., BASHAN, A., BARTELS, H., AGMON, I., FRACESCHI, F. eta YONATH, A. 2000. «Structure of functionally activated small ribosomal subunit at 3.3 A resolution». Cell, 102, 615-623. 